\title{
Impact of Incremental Surface Soil Depths on Infiltration Rates, Potential Sediment Losses, and Chemical Water Quality
}

\author{
STEVEN M. LYONS AND GERALD F. GIFFORD
}

\section{Abstract}

A study was conducted between October 1974 and August 1976 to measure the effects of incremented surface soil depths on infiltration rates, potential sediment production, and chemical quality of runoff water. The treatments were incremental removals of 7.6-cm soil layers to a depth of $30.5 \mathrm{~cm}$ on two pinyon-juniper sites in Utah. Hydrologic parameters were measured at each $7.6-\mathrm{cm}$ incremental soil depth using a Rocky Mountain infiltrometer. With one exception, no significant differences occurred in infiltration rates among treatment depths during either 1975 or 1976 at either the Blanding (southeastern Utah) or Milford (southwestern Utah) site. A significant change in infiltration capacities was noted between the 1975 and 1976 field seasons when data from both treatment depths and study sites were pooled. There were no significant differences in potential sediment production between sites or among treatment depths at a site. In terms of chemical water quality, a significant change in phosphorus content of runoff waters was observed at the Blanding site between the 1975 and 1976 field seasons. Significant differences in potassium concentrations were found between sites and among soil depths. Nitrate concentrations were very low in runoff waters from all soil depths at both sites.

With continued intrusions by man on wildlands through increasing use of offroad vehicles, grazing of domestic livetock, other agriculture, strip mining, especially in the semiarid rangelands, a more comprehensive understanding of the cause and effects of soil erosion is essential. Many published reports have dealt with soil erosion by water (including the effects of vegetal cover, soil textures, slope, aspect, etc. on erosion) and on infiltration-erosion relationships. Little or no information, however, has been published on how incremental soil losses (or perhaps soil profile reconstruction in mining reclamation work) affect plant production and related processes and hydrologic parameters such as infiltration rates, sediment production, and the chemical water qualities of runoff water.

The objective of this study was to determine if infiltration rates, sediment losses, and chemical qualities of surface runoff waters would be affected by various incremental surface soil depths at two pinyon-juniper sites (Pinus spp.Juniperus spp.) in Utah.

\footnotetext{
Authors are graduate research assistant and professor, Rangeland Hydrology, Watershed Science Unit, College of Natural Resources, Utah State University, Logan, 84322. Mr. Lyons is currently hydrologist with the Bureau of Land Management, Montrose, Colorado.

This study was supported in part by the Utah Agricultural Experiment Station (Proj. 749) and in part by the Office of Water Research and Technology, Dept. of Interior (Grant A-022-Utah), in cooperation with the Bureau of Land Management, Journal Paper 2378, Utah Agricultural Experiment Station, Logan, 84322.

Manuscript received November 16, 1978.
}

\section{Methods and Procedures}

\section{Site Description}

Two Utah sites were selected for this study, one in the southeast near Blanding, and one in the southwest near Milford.

\section{Blanding Site}

The Blanding site is about $70 \mathrm{~km}$ west of Blanding, Utah, in the N.E. $1 / 4$ of T38S, R 18E, near Coyote Flat. Elevation is about 1,981 meters, with a 30-year (1931-1950) average annual precipitation of about $28 \mathrm{~cm}$ per year, of which about $13 \mathrm{~cm}$ falls between May and September. The soils are derived from sandstone-siltstone and are of the Aridic Argiustolls-Typic Argiustrolls association. The texture is sandy loam and the color is red (Gifford 1973). The $\mathrm{pH}$ ranges from 7.7 to 8.1 with a total nitrogen percent of 0.13 to 0.21 . The area was double-chained in the fall of 1967 and broadcast seeded to crested wheatgrass (Agropyron cristatum) at a rate of 9.1 $\mathrm{kg}$ per hectare. Grazing has been excluded.

\section{Milford Site}

The Milford site is about $72.4 \mathrm{~km}$ west of Minersville, Utah, in the S. $1 / 2$ of Section 7, T30S, R15W. Elevation is 2,100 meters. The annual precipitation averages about $36 \mathrm{~cm}$, with $15 \mathrm{~cm}$ falling from May to September. The soils are from the Xerollic CalciorthidsXerollic Paleorthids assocation and have a silt loam texture (Gifford and Tew 1969). The $\mathrm{pH}$ ranges from 7.2 to 7.4 , and organic carbon ranges from $0.7 \%$ to $1.7 \%$. This site was double-chained in the fall of 1967 and broadcast seeded to crested wheatgrass. Grazing has been excluded.

\section{Sampling Procedure}

The dependent variables of interest in this study were: (1) infiltration rates, (2) potential sediment losses, and (3) phosphorus, potassium, and nitrate concentrations of runoff watcrs. These parameters are all highly related, and through the use of a rainfall simulator (or infiltrometer), data for all three may be obtained simultaneously.

We used a Rocky Mountain infiltrometer (Dortignac 1951). This infiltrometer is equipped with a sprinkler head that has three Type $F$ nozzles, a $0.25-\mathrm{m}^{2}(76.2 \mathrm{~cm} \times 30.5 \mathrm{~cm})$ plot frame that is driven approximately $2.5 \mathrm{~cm}$ to $7.0 \mathrm{~cm}$ into the ground, a wind screen that shelters the water drops, collection buckets and hoses for recovery of runoff water with sediment, and a water supply tank mounted upon a trailer.

All plots were pre-wet approximately 16 to 20 hours prior to the application of simulated rainfall to eliminate confounding effects of any antecedent moisture. Rainfall was simulated at an average rate of $8.2 \mathrm{~cm}$ per hour for 28 minutes. Runoff water was collected and measured 3 minutes after rainfall began and thereafter at 5minute intervals to determine infiltration rates. Integrated subsamples of runoff waters were analyzed for phosphorus, potassium, and nitrate contents. An additional 0.95 liters of each integrated subsample was used to determine total sediment production (kilograms of oven-dry sediment per hectare).

Thirty large soil pits were dug at each of the two sites during the 
early summer of 1975 . Each pit contained three random 7.6-cm incremental soil sampling depths (randomized from the 0, 7.6, 15.2, 22.9, and 30.5-cm soil depths). Fifteen soil pits allowed, therefore, nine replications of each treatment. Fifteen soil pits were utilized the first summer (1975) for infiltration, sediment production, and chemical water quality measurements. The remaining nine replications ( 15 soil pits) of each treatment remained exposed to the environment, but untreated for one year, and were then utilized during the summer of 1976.

\section{Results and Discussion}

\section{Infiltration}

Examination of the analysis of variance for infiltration rates revealed a site by treatment-depth interaction and a rainfall duration by year by site interaction. Figure 1 shows the relationship between the Blanding and Milford sites and between depths at a site. A significant difference existed between sites for all depths except at $30.5 \mathrm{~cm}$. The high infiltration capacities at the Blanding site are attributed primarily to soil texture, the Blanding site being a sandy loam while the Milford site is silt loam in texture.

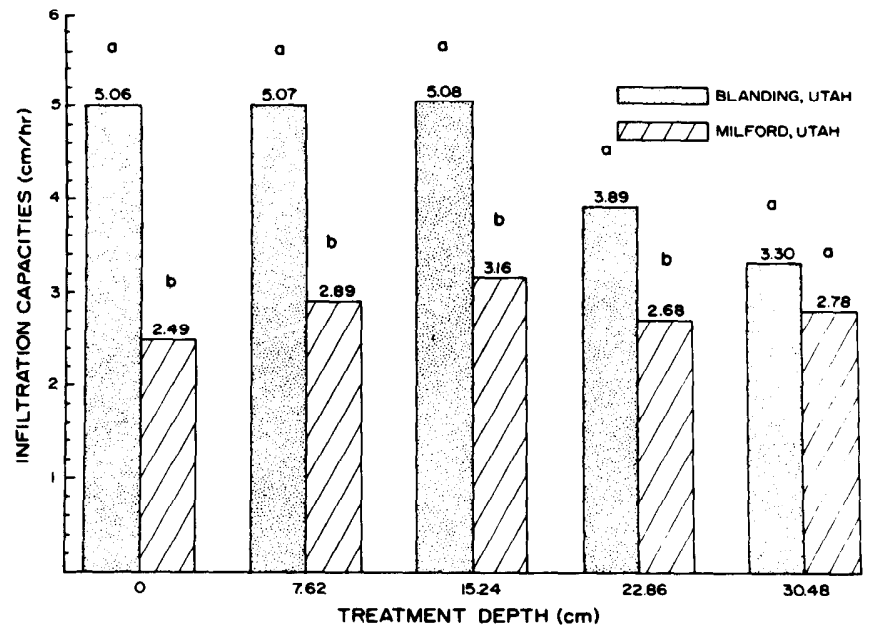

Fig. 1. Infiltration rates for the four subsoil treatments and the surface control for Blanding and Milford study sites. Data are pooled over all time periods within an infiltrometer run and over 2 years. Any pair of bars with the same subscript are not significantly different at the .05 level of probablility.

Because of the significant difference in infiltration capacities between sites, the storm-duration by year interaction was examined next (Fig. 2). Infiltration capacities may change from year to year, or even season to season, because of variable climatic conditions, vegetation development, and soil conditions (Gifford 1979). The slight decrease (1975 vs 1976 seasons) in infiltration capacities after 28 minutes at both sites was probably due in part to fine soil particles being deposited within the exposed soil pits (treatment plots) by wind action during the 1975-76 year. Fine soil particles would clog surface pores, thus decreasing infiltration capacities.

\section{Chemical Quality of Runoff Water}

The water quality parameters of interest in this study were the elements that may be limiting to plant production in semiarid rangelands and that are subject to loss with runoff water. These elements are nitrate nitrogen, phosphorus, and potassium. Nitrate nitrogen measurements had been taken previously by Buckhouse and Gifford (1976) at other sites, and preliminary measurements were attempted in this study. In all cases, however, the quantities of nitrate nitrogen present in runoff waters were extremely low, so measure-

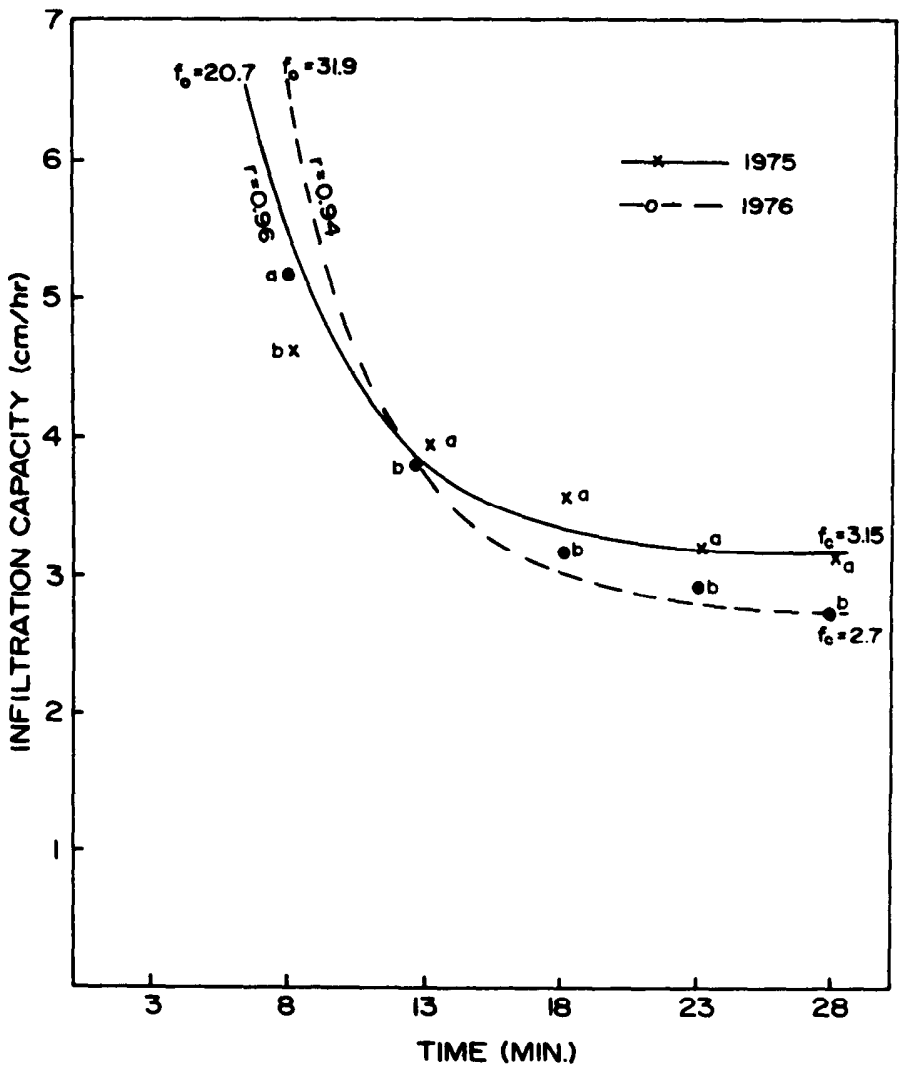

Fig. 2. Infiltration capacities between years as pooled over depths and locations. Infiltration curves were fitted to measured infiltration rates using Horton's equation (1939, 1940). Any pair of plotting points with the same subscript are not significantly different at the .05 level of probability.

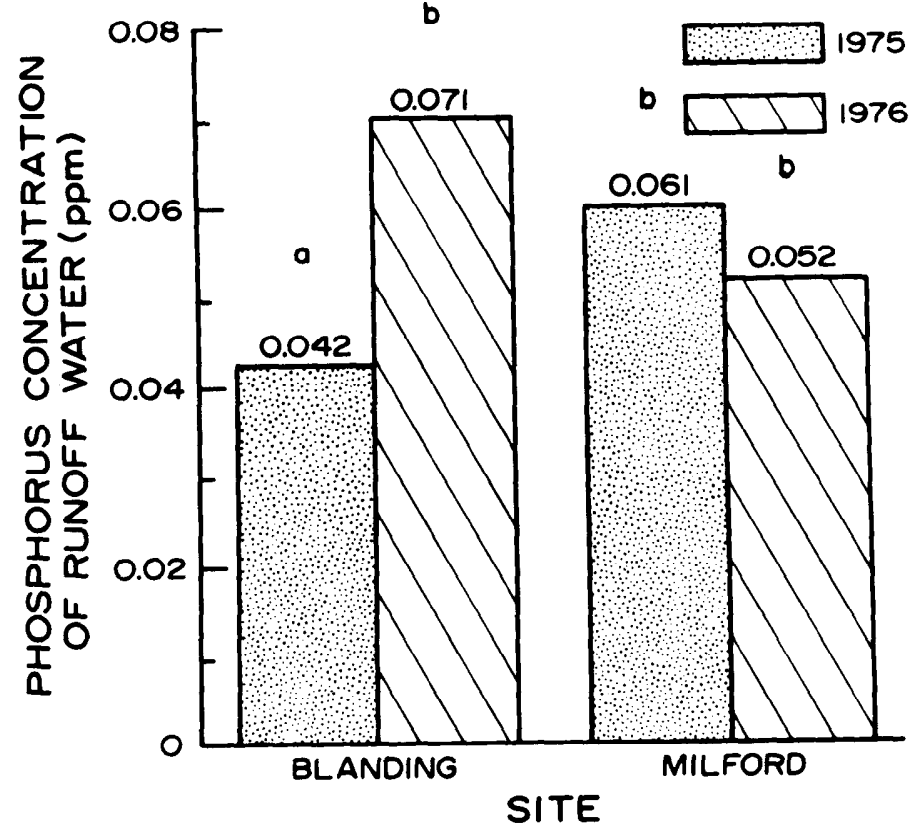

Fig. 3. Average phosphorus concentrations of runoff water for Blanding and Milford sites as pooled over all treatment depths. Any bars with the same subscript are not significantly different at the .05 level of probability. 


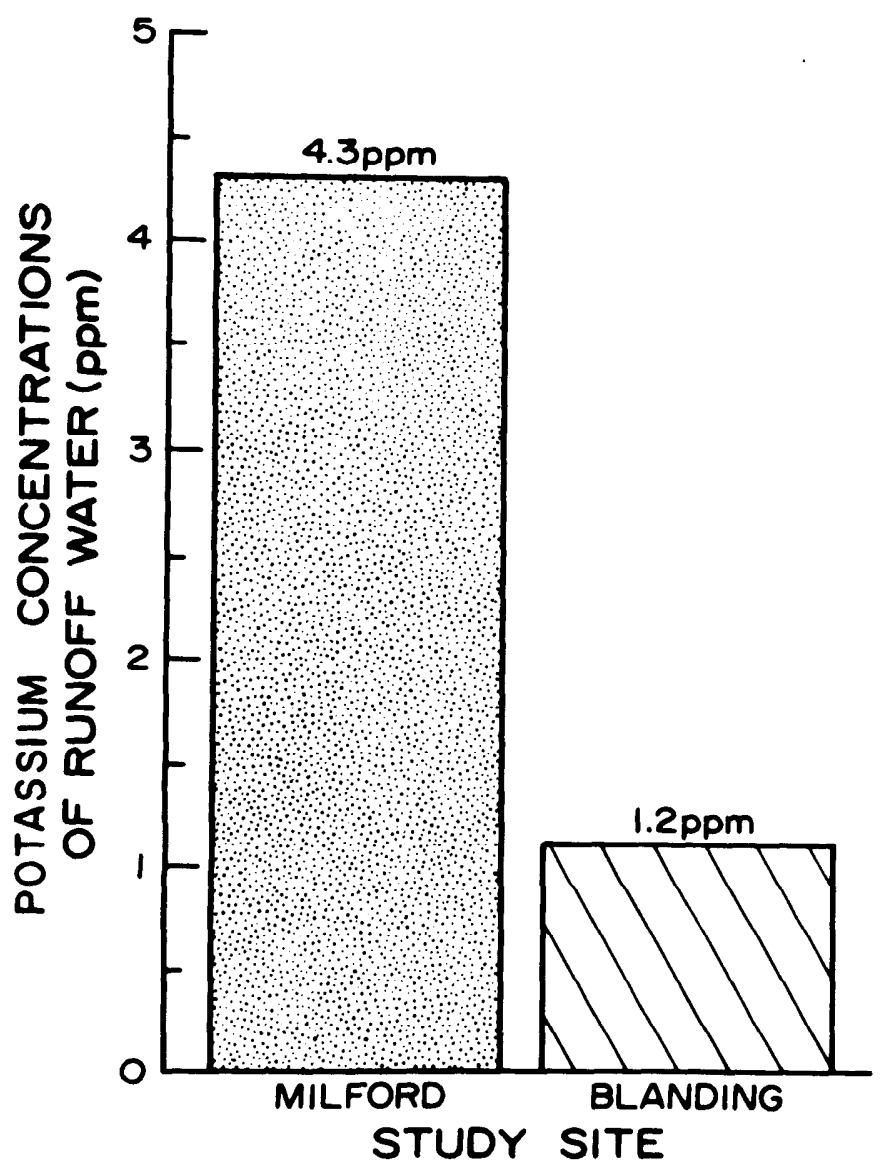

Fig. 4. Potassium concentrations of runoff water for Blanding and Milford site. Data pooled over depths and years.

ment efforts were discontinued.

Our analyses of variance for phosphorus concentrations of the runoff water showed a significant year by site by treatment-depth interaction. A year by site interaction was also significant, and further analysis of this interaction revealed that only the phosphorus concentration of the 1975 runoff water at the Blanding site differed significantly from the average for both sites (Fig. 3).

Significant differences in potassium concentrations were found between sites (Fig. 4) and among treatment depths (Fig. 5). The site differences parallel the potassium concentrations found in the two soils (Lyons and Gifford 1980, Table 1).

\section{Potential Sediment Production}

Measurements of sediment losses revealed no significant differences either between sites or among soil depths, despite site differences in soil texture. As can be seen in Table 1,

Table 1. Average sediment production ( $\mathrm{kg} / \mathrm{ha}$ ) values for the two sampling sites during 1975 and 1976.

\begin{tabular}{lccccc}
\hline \hline & \multicolumn{5}{c}{ Soil depth $(\mathrm{cm})$} \\
\cline { 2 - 6 } Study Site & 0 & 7.6 & 15.2 & 22.9 & 30.5 \\
\hline 1975 & 1302 & 6046 & 9933 & 1701 & 1710 \\
$\quad$ Blanding & 1217 & 4512 & 2358 & 2136 & 1066 \\
$\quad$ Milford & & & & & \\
1976 & 1551 & 4089 & 8467 & 1750 & 2473 \\
$\quad$ Blanding & 3552 & 5260 & 4509 & 4528 & 2801 \\
$\quad$ Milford & & & & & \\
\hline
\end{tabular}

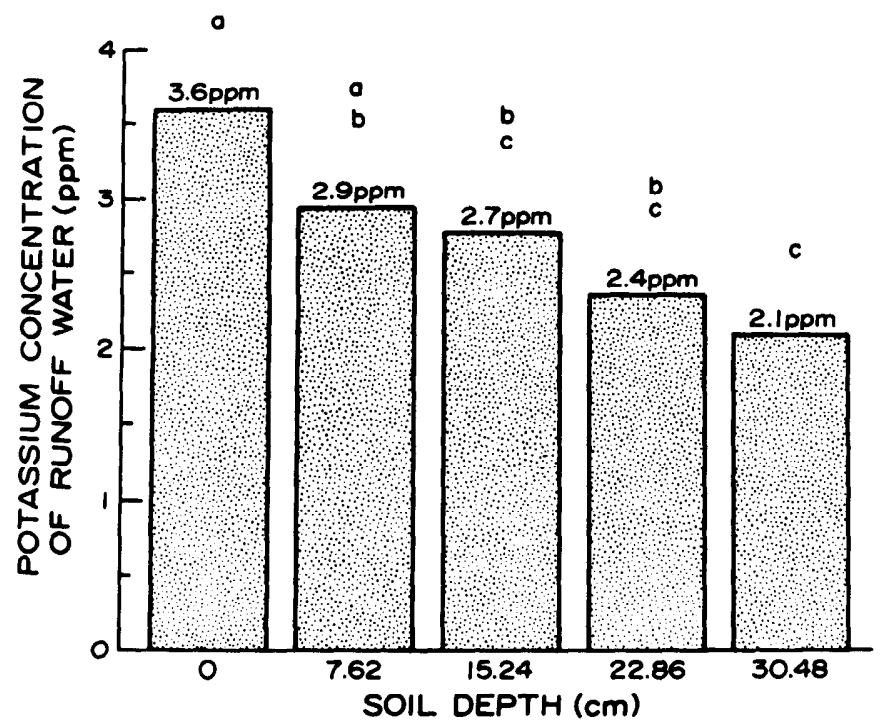

Fig. 5. Potassium concentrations of runoff water for all treatments as pooled over both sites and years. Any bars with the same subscript are not significantly different at the .05 level of probability.

sediment production values ranged from 1,065 to 9,933 $\mathrm{kg} / \mathrm{ha}$.

\section{Summary and Conclusions}

There were no significant changes in the hydrology and water quality variables studied (infiltration capacities, potential sediment production, and water quality) with the removal of the first $7.6-\mathrm{cm}$ layer of soil. At the Blanding site, no significant differences occurred in infiltration capacities down to a depth of $15.3 \mathrm{~cm}$. A significant decrease, starting at $22.9 \mathrm{~cm}$, was probably due to a calcareous hardpan development that began at about $20 \mathrm{~cm}$ below the surface. No significant differences among treatment depths were found at the Milford site.

Infiltration capacities differed significantly between the two study years when data from both sites and all treatment depths were pooled. Infiltration rates at the end of $28 \mathrm{~min}$ utes as measured during the second season decreased some $14 \%$ from the first year. This difference may have been caused in part by clogging of soil pores by windborne dust particles during the year that subsurface soils were exposed to the environment.

Significant differences were found in the phosphorus and potassium concentrations of the runoff waters at the two sites. These differences strongly paralleled the phosphorus and potassium concentrations of the soils at the two sites. Potassium concentrations decreased significantly with depth, but phosphorus concentrations did not. More research is needed to determine how losses of nutrients in runoff water affect plant production.

Our measurements of potential sediment losses revealed no significant differences either between sites or among soil depths despite site differences in soil texture.

\section{Literature Cited}

Buckhouse, J.C., and G.F. Gifford. 1976. Grazing and debris burning on pinyon-juniper sites-some chemical water quality implications. J. Range Manage. 29: 299-301.

Dortignac, E.J. 1951. Design and operation of Rocky Mountain infiltrometer. U.S. Dep. Agr., Forest Serv., Rocky Mt. Forest and Range Exp. Sta. Pap. No. 5: 68 p.

Gifford, G.F. 1973. Runoff and sediment yields from runoff plots on chained pinyon-juniper sites in Utah. J. Range Manage. 26: 440-443. 
Gifford, G.F. 1979. Infiltration dynamics under various rangeland treatments on uniform sandy loam soils in southeastern Utah. J. Hydrol. 42: 179-185.

Gifford, G.F., and R.K. Tew. 1969. Evaluating rangeland water quality with small plot infiltrometers. J. Soil and Water Conserv. 24: 65-67.

Horton, R.E. 1939. Analysis of runoff-plot experiments with varying infiltration capacity. Trans. Amer. Geophys. Union 20: 693-711.
Horton, R.E. 1940. An approach toward physical interpretation of infiltration capacity. Soil Sci. Amer. Proc. 51: 399-417.

Lyons, S.M., and G.F. Gifford. 1980. Impact of surface soil removal on plant production, transpiration ratios, and nitrogen mineralization rates. J. Range Manage. 33: 189-196. 